\title{
THE EBB AND FLOW OF SCIENCE AND RELIGION RELATIONSHIP IN AFFECTING HUMAN LIFE
}

\author{
Ridha Ahida \\ State Islamic Institut of Bukittinggi \\ Kubang Putiah, Banuhampu, Agam, West Sumatera \\ E-mail: ridhaahida@iainbukittinggi.ac.id
}

\begin{tabular}{c|c|c}
\hline Received: & Revised: & Approved: \\
$17 / 03 / 2020$ & $27 / 04 / 2020$ & $10 / 06 / 2020$ \\
\hline
\end{tabular}

DOI: https:// doi.org/10.32332/akademika.v25i1.2372

\begin{abstract}
(c) (†) (O)
The Ebb And Flow Of Science And Religion Relationship In Affecting Human Life Licensed Under a Creative Commons AttributionShareAlike 4.0 International License
\end{abstract}

\begin{abstract}
This research aimed at discovering the root of the problem of the relation between science and religion, identifying how conflict and collaboration between science and religion answer the challenges that human life pose and describing how religion in the future synergize with the advancement of science. This research emphasizes on the need to delve on the issues related to science and religion since the advancement of science often contradicts with some aspect of the Holy Book as well as the assumption that science rattles someone's faith. Religion is also often regarded as something that hinders the development of science and people who participate in science development are often considered an infidel. There is a skeptical nuance that arose regarding the relationship between science and religion. Thus, it is of utmost importance to investigate on the ebb and flow of science and religion relation in affecting human life. This research employed methodology of philosophy, especially science philosophy in the form of justification and history of science. This research indicated that science and religion are both collaborating and confronting. Religion is used to make meaning of life and science is used to make life easier.
\end{abstract}

Keywords: Religiosity, Rationality, Confrontation, and Collaboration 


\section{A. Introduction}

There are skeptical nuances that arouse every time the issue related to science and religion is being discussed. The secrets of life that are used to be considered sacred have been uncovered by the development of science 1 . Science enables humans to identify themselves and their environment and to further adjust themselves with the environment they live in. Science has slowly been able to replace the prerogative right of God on the universe and human beings. This has been the source of concern and enmity of the religionist toward the development of science ${ }^{2}$

Science and religion have been discussed by many philosophers, scientists, and religionists. Ian G Barbour (1997) described contemporary issues related to the human understanding of the existence of God and truth as well as a religious practice in the scientific era and there was four typology between science and religion ${ }^{3}$

Betrand Russell (1997) discussed the conflict between science and religion in the traditional context at the end of the 14th century ${ }^{4}$. One of the latest research concerning science and religion was conducted by Izak J. Van der Walt. He insisted that the recent scientific discovery on biochemistry and paleontology has made scientists gradually accept that God is the creator of the whole universe as mentioned in the Holy Book. Recent scientific discovery has given Theology as well as reformed Theology a special position as it is related to the belief in the existence of power beyond human 5 .

This research is different from previous researches. It discusses the relationship between science and religion in affecting human life in the context of justification and the history of science. The ebb and flow of the relationship between science and religion are determined by the truth of claims from science and religion itself. It also discusses the root problems of the science development on religion and patterns of future religious activities that are synergized with the advancement of science-based on justification and the history of science in human.

1 Syarif Hidayatullah, "Agama Dan Sains: Sebuah Kajian Tentang Relasi Dan Metodologi," Jurnal Filsafat 29, no. 1 (2019): 118-120.

2 Peter Harrison, The Territories Science and Religion (Laondon: The University of Chacago Press, 2015).

3 Luthfiyah, "Mengurai Kebekuan Hubungan Agama Dan Sains Melalui Pemahaman Saintific Method Perspektif," Muaddib: Studi Kependidikan dan Keislaman 09, no. 01 (2019): 81-84.

4 D. H. Lawrence adn Betrand, A Prison for Te Infinite, n.d.

${ }^{5}$ Izak J. Van Der Walt, "Reformed Theology and Natural Science: Conflict or Concurrence" (2020). 


\section{B. The root of problems of the science development}

Science is one of the greatest achievements in the history of human life. The discovery and development of science can solve human problems and provide a series of conveniences in human life. The advancement of science has produced brilliant achievements in human life. All of these advancements are indeed amazing and should be appreciated. These advancements include humans progress in exploring and exploiting natural resources as well as dealing with the tremendous challenges of nature $^{6}$

Science doesn't only offers knowledge, it also offers mastery of something. As a result, humans are obsessed with seeking and mastering science. Science is constantly developing and perfecting its previous form. It was proven by history that humans have discovered and used science from simple to complex matters 7 .

Before the modern century or before the industrial revolution, science was used as a way of knowing something which is science for science. By the 17th century, a new chapter appeared in the history of science development. At that time, science was developed as the only goal of human life which gave science "a special position" to legitimize and to demonstrate human autonomy. The development of science in the modern age has opened the eyes of every human being to another world. It also overturned old discoveries that were no longer suitable for their ages ${ }^{8}$.

Three branches of science have pioneered the science development, such as mathematics, physics, and astronomy. Sir Isaac Newton (1643-1727) discovered the theory of gravity, calculus (differential integral), and optics, which were used as the basis for further scientific developments. These inventions emerged and they were used to improve, replace, or even criticize previous inventions. The development of science is dynamic, as is seen in Albert Einstein's theory of relativity (1879-1955) that has fundamentally changed views of space and time, as well as Max Planck's

${ }^{6}$ Hidayatullah, "Agama Dan Sains: Sebuah Kajian Tentang Relasi Dan Metodologi."

7 Syarif Hidayatullah, "Konsep Ilmu Pengetahuan Syed Hussein Nashr: Suatu Telaah Relasi Sains Dan Agama," Jurnal Filsafat 28, no. 1 (2020): 116-117.

8 Wulan Izzatul Himmah Anggun Zuhaida, Nur Hasanah, "Model Madrasah Sains Integratif: Menakar Konsep Dan Strategi Pembelajaran Berbasis Relasi Sains Dan Agama," Inferensi: Jurnal Penelitian Sosial Keagamaan 12, no. 2 (2018): 439-440. 
quantum theory that has changed views of energy along with Darwin's theory of evolution ${ }^{9}$

Moreover, the emergence of a new branch of science like humanities which include, sociology, economics, and psychology should also be acknowledged since they are uncovering what happens to humans along with laws and aspects that affect human life itself. After World War II, the development of science began to enter a new phase which is space exploration. Apart from space exploration, visible cells are also the research objects of biologists. Then, it developed a new science called biotechnology which includes biochemistry, biophysics, and microbiology. Science can compile egg cells and sperm cells through a chemical process and then create humans by using experimental tools in the laboratory. They are even able to create the traits and talents of human creation ${ }^{10}$

Undeniably, modern humans have embraced an excessive technological mentality. This is reflected in the excessive trust in tools (techno-centric). They believe that technology can be a problem-solving tool used for almost everything. The glorious achievements that were made through the advancement of sciences are indeed admirable and deserve to be grateful. However, it tempted humans to think of himself as the master of all. By using science, humans can help themselves, but at the same time, they can also destroy themselves. The crucial role of science in human life makes human functions not only as a player but also as a card that is being played. In other words, science can be both beneficial and disastrous. Thus, there is ambivalence in science development ${ }^{11}$.

Humans are starting to realize that science is not everything. It is not what was expected before. Although science can answer so many problems, it seems impossible for science to answer all emerging problems. Sometimes, science creates and causes more problems. We don't have to overly trust that science is a solution to social, relational, personal, or existential problems. Science in its further development requires control of other values, at least in solving science problems, because it cannot be used as a foundation for human life ${ }^{12}$

9 Mulyadi Abdul Wahid dan Abd Mujahid Hamdan Muhammad Zaini, "Alquran and Modern Geoscience," Elkawnie: Journal of Islamic Science and Technology 6, no. 1 (2020): 15-16.

10 Zaprulkhan, "Membangun Relasi Agama Dan Ilmu Pengetahuan," kalam: Jurnal Studi Agama dan Pemikiran Islam 4, no. 1 (2019): 261-264.

${ }^{11}$ Edwin Syarif, "Pergulatan Sains Dan Agama," 201313 (2013): 648-652.

${ }^{12}$ Fahri Hidayat, "Pengembangan Paradigma Integrasi Ilmu: Harmonisasi Islam Dan Sains Dalam Pendidikan," Jurnal Pendidikan ISlam IV, no. 2 (2015): 302. 


\section{Science and Religion: The Endless Conflict}

Since a long time ago, there has always been a "tension" between science and religion. We don't need to be naive, lose our critical character and close our eyes to the historical fact that in the past, in the present, and maybe in the future, conflicts between science and religion will always occur. The conflict between science and religion is driven by differences in legitimizing something. For centuries, the historical relationship between religion and science represents a "war model"13

From a religious perspective, science is a world product that should be avoided because it is considered to be a damaging factor of religious doctrine. This opinion has been possessed by every religious adherent and they also consider science as "mortal enemy". On the other hand, science also considers religion something that is conservative, irrational and it does not have a clear epistemological basisit ${ }^{14}$

In pre-scientific age, power belonged to God. There is a presumption that it is not much that humans can do even though they are in their best conditions. Things will get worse when God's wrath comes. Humans must always be aware of their weaknesses, and always be ready to admit them. From the science perspective, everything is different; humans can arrange everything by using knowledge of natural laws. The power of science is more reliable than the power of prayer. In the past, humans did not believe that they could move mountains, but by using the bomb it became possible for humans. Some human activities will have beneficial effects, and some will be harmful. All of them demonstrate human power ${ }^{15}$

Before the modern century (the 17th century), the pre-renaissance and industrial revolution or scientific revolution, human thoughts and science discoveries were strictly controlled by religious circles. Science must obey the provisions of the church, mischievous scientists are punished and science was used as a tool to legitimize church power. The birth of modern science has widened the gaps in science and religion. Galileo Galilei (15461642), who criticized the old geocentric cosmology by proposing a new heliocentric idea, is one of several shreds of evidence of the "judgment" of the religionists against scientists. The problem between religionists and

${ }^{13}$ Ibid.

14 Anda Juanda, "Penetrasi Agama Dan Ilmu Sains Berbasis Model Kurikurum Grass Roots Perguruan Tinggi," Educatia: Jurnal sains dan Pendidikan Sains 5, no. 1 (2016): 71-72.

${ }^{15}$ Cindy Elsa Anggraini dan Ahmad Fauzan Hidayatullah Muhammmad Ainul Yaqin, Evi Widia Astuti, "Integrasi Ayat-Ayat Al-Quran Dalam Pembelajaran Sains (Biologi) Berdasarkan Pemikiran IAN G. Barbour" (n.d.): 7879. 
scientists is not as simple as what is often thought. It is a conflict between rational and irrational thought, advanced and conservative thought. For centuries, people believed in the geocentric view of the world and that faith of God is also associated with the view. Heliocentric is considered to be contradicting with the religious teachings and divine faith. Therefore, scientists who propose this theory and their adherents should be punished because it can mislead the people and destabilize the credibility of the church $^{16}$.

Charles Darwin (1809-1882) was considered as "defendant" by religious circles. He has caused conflict between science and religion in the 19th century until the beginning of this century, and it continues until now. Darwin's theory interferes with the foundations of Christian belief, that human was created by God and that human was created in God's image. Humans are created from an evolutionary process and their ancestors were apes. Furthermore, in the Holy Book, the story of the creation of the world in seven days is also rejected. The world is created in millions of years. Darwin's theory cannot be accepted, because the Holy Book is a revelation from God, therefore, Darwin must be punished ${ }^{17}$.

The conflict between science and religion is getting more complicated and it continues until now, it is endless conflict. Religions are constantly questioning the new biological discoveries in the medical field which are considered to be contradicting with religion, for example, IVF is used for those who are infertile and can not carry babies. To control science discoveries, religionists release a series of laws in categorizing them: halal or haram (prohibited or not), may or may not, must be punished or may be exempted. Scientists ignore the religionist attitude towards the development of science that is considered contradicting with religion and criticizing the existence of science. They are increasingly motivated to reveal the sacredness of the secrets of human life and they proclaimed their objection that religious authorities should not interfere with their affair ${ }^{18}$ ).

The Renaissance that occurred before the 17th century was a new chapter in the history of human thought. Renaissance is a form of scientist protest to criticize the legitimacy of the church over all areas of human life.

${ }^{16}$ Muhammad Priyatna, "Telaah Kritis Konsep Ide Besar (Fritjof Capra), Anything Goes (Paul Peyerabend) Dan Krisis Sains Modern (Richard Tarnas) Dalam Upaya Rekontruksi Pemikiran Pendidikan Islam," Edukasi Islami: Jurnal Pendidikan Islam 08, no. 01 (2019): 125-126.

17 Muhammad Miftah, "Model Integrasi Sains Dan Agama Dalam Pendidikan Nasional," Jurnal Penelitian 14, no. 2 (2017): 235-236.

18 Iis Aripudin, "Integrasi Sains Dan Agama Dan Implikasinya Terhadap Pendidikan Islam," Jurnal Edukasia Islamika I, no. 1 (2016): 162-163. 
The following centuries were marked with scientific developments that emerged during the renaissance. Humans continue in seeking and in proving all aspects of life scientifically. Humans have been aware of their existence as human beings who are free from arbitrary traditions and power as shown by the religionists in the middle ages .

Human thought has produced science discoveries that interfere with the credibility of religion and religionists, such as the theory of biological evolution, the physical theory of natural laws, and astronomy. Previously, something that is considered holy or sacred by religious dogma is being investigated and tested by using the scientific method. Humans can find their world without the help of divine assistance. In ancient ages, all areas of life were controlled by religion. Today, however, many areas of life have been separated from this control, they have become autonomous fields with their values. Through humans' success in answering the problems, humans are aware that with their autonomy and their abilities, they can shift all religious explanations. However, human struggle to gain autonomy and to escape from religious interference through science has caused increasingly sharp tensions ${ }^{19}$.

\section{Positivism: Rejection of Metaphysics and Religion}

There are radical changes in modern humans live in identifying themselves as well as exploring the world that they live in. For thousands of years, human beings have adopted various schemes in making meaning and in interpreting the world. Humans have always used the outside objective as schemes in making meaning and interpreting the word. Therefore, humans live in familiarity with their environment and experience certainty about the truth they are trying to achieve. Even though humans get life schemes from religious beliefs, metaphysics, intuition, and feelings, they think that their knowledge is objective and realistic. Traditional humans believe that their ideas about the world reflect the outside reality ${ }^{20}$.

Descartes' doubts started a modern thought which classified all knowledge originating from religion, metaphysics, and feelings as subjective and unscientific. Sensory observation is the only reliable source of knowledge. The image of the world and the image of humans become different. In other words, humans can only speak correctly about the reality

19 Wedra Aprison, "Mendamaikan Sains Dan Agama," Pendidikan Silam IV, no. 2 (2015): 2015.

${ }^{20}$ Chafid Wahyudi, "Etika Publik Sebagai Ruang Dialog Agama," Hikmatuna 1, no. 1 (2015): 36-37. 
of nature if he confines himself to the primary characteristics, such as weight, volume, temperature, length, and so on, which can be experienced through the five senses and it is formulated mathematically.

The universe is moved under the influence of natural laws. At the beginning of the new age, Allah was still recognized as the Most Greatest Who had created the mechanisms of nature, but later this belief was ignored because it was irrelevant. All nature is created in terms of the usual natural causes and processes. As a result, the world was not considered a sacred nature. In the past, the sun was respected because it was full of mystery, but now such an understanding is considered an anachronism ${ }^{21}$.

In the 17th and 18th centuries, concepts for a mechanical and mathematical view of the world were developed more frequently. Science becomes the goal in itself, independent, autonomous, and free from philosophy and religion. Science is founded based on several assumptions formulated as laws and it is believed that scientific knowledge must be objective. It means that a scientist must not be influenced by factors that come from within him, such as feelings, beliefs, ethical values that make him praise or criticize the object studied, philosophy, religion, theology, or anything that is not directly displayed by the object under observation. Objectivity is the only way to obtain scientific truth. Furthermore, science is inter-subjective; it means that science must be general. It must be proven and tested by more than one person based on observation.

Auguste Comte (1798-1857) is considered as the father of positivism because he popularized and interpreted this term. Positivism is a philosophical notion that emerged in the 19th century which tended to limit human true knowledge to things that could be obtained by using scientific methods. This concept is rooted in the realism ontology which states that reality exists in reality which runs according to the natural laws. The research effort is only to reveal the truth of the existing reality and how reality works.

Positive things are things that must be confirmed by everyone who has the same opportunity in judging. This thing underlies and forms science. Therefore, this concept contradicts the events that exist only in our imagination. Only facts or things that can be reviewed and tested can underlie valid knowledge. Thus, metaphysics and religion are regarded as wild speculation. Comte rejects the ancient way of thinking in which daily

${ }^{21}$ Rd. Datoek A. Fchoer, "Sekularitas Dan Sekularisme Agama," Religious: Jurnal Agama dan Lintas Budaya 1, no. September (2016): 99. 
experience and religious feelings is the correct interpretation and understanding. Positivism forces religion and metaphysics to abdicate ${ }^{22}$

Comte believes that the ability of human thought in perceiving world phenomena is limited. Therefore, humans must be modest in their aspirations in seeking knowledge. Humans must limit their efforts and process in terms of objective and tangible sensory data. Three things that humans must do, namely:

1. Accept and justify empirical symptoms as reality

2. Collect and classify the symptoms according to the law

3. Predict future events based on these laws and take necessary and useful actions

According to Comte, people in positive ages can't accept values and belief systems used in the middle ages because they were considered outdated. The religious idea that underlies the unity of society is now challenged by the evolutionary process and must be abandoned. Since the higher stages of evolution have become a necessity, then higher belief systems and values must be accepted. The traditional function of religion as a unifying society must be taken over by positive science. The historical role of the religionist must be shifted to scholars, engineers, and industrialists ${ }^{23}$.

The unity of human beings is not determined by national or ethnic characteristics but by the similarity of senses and the intellectual structure. The similarity in the structure of the senses and reason produces the same perceptions and logical conclusions. Due to this similarity, human development throughout the world shows unity based on similar laws. The way humans think and interpret the world develops gradually, such as the religious, metaphysical, and positive stages ${ }^{24}$.

1. The religious stage

At the beginning of the development of human thought, the religious idea was used to explain all phenomena and events. Since human hasn't recognized himself as a human being who has power over other things, human experiences his existence in the world as part of a whole that is both

22 al Barra Sarbaini, "Agama Dalam Perfektif Masyarakat Madani," AthThariq 02, no. 01 (2017): 4.

${ }^{23}$ Irham Nugroho, "Positivisme Auguste Comte : Analisa Epistemologis Dan Nilai Etisnya Terhadap Sains," Cakrawala XI, no. 2 (2016): 170-171.

${ }^{24}$ Kenneth S. Sacks, "Auguste Comte and Consensus Formation in Religious Thought," Religions (2017): 4. 
amazing and terrifying. Ancient humans lived their life as participation in cosmic processes beyond their simple thought.

\section{The metaphysical stage}

At this stage, all symptoms and events are no longer seen to be directly caused by a spirit, god, or the Almighty. Currently, human thought seeks understanding and explanation by making abstractions and metaphysical concepts. This stage is a modification of the first stage. Although the principle of natural illumination is sought in nature itself, this information is not based on empirical facts but it is based on a presupposition or a priori.

\section{The positive stage}

At this stage, natural phenomena are explained by thought based on its laws which can be reviewed, tested, and proven empirically. This explanation produces instrumental knowledge. In this positive stage, religion must surrender its hegemony over the area of thought to empirical science.

According to Comte, the simpler and the more universal the structural symptoms of something, the easier the interpretation associated with religion or metaphysics is will be abandoned it will be later replaced with positive interpretations. Positivistic thought teaches people to pay attention and to know only physical and material symptoms. The consequence of the way of thought is a loss of awareness of spiritual values that are sacred and transcendental.

\section{E. The Influence of Science on Human Religiosity}

Religion affects the development of society. The development of the people's mindset will determine the understanding and pattern of the community's diversity. Therefore, the model of human religiosity is always developing. In modern ages, religiosity is not as simple as it was in the past. Thus, it's not fair if we equalize the conditions. The current scientific mentality is often blamed as the main cause of the religious crisis. The development of science is considered to have misled religious communities and the credibility of religions, especially religionist.

The development of science has tempted humans to deny religion and God. Science has gradually replaced God's "prerogative" towards nature and human. Human can discover science without being dependent on anything. Humans are no longer dependent on Divine elements which are considered to be too complicated. Progress is considered impossible if humans are bound by religion. Religion is unable to provide or even to 
offer happiness in the world because of the live herafter as it's main purpose. Therefore, religion and God "must be excluded" from human life.

We often hear negative views about the influence of the development of science on human life. It is understandable because we only observed it as an ousider of science, thus, enabling false spontaneous impression to emerge. In fact, if we are to be honest, there are many contributions from science to human religiosity, especially in this century which is completely erratic and almost out of control. Science has helped humans to have faith and religion in a more conscious and responsible way. Science has also helped religion to reflect critically on faith and to put the nature, function and God's existences 25 .

God's power is incomparable to human power. The assumption that if humans are more powerful is wrong because God's power will be increasingly strong. God, the Creator, should more exalted when humans achieving more success in life. Science has helped human to utilize the God's gift by doing good deeds. Thus, it seems reasonable that the current model of religiosity is the religiosity of scientists and technocrats rather than religious scientists or religious scholars who is still busy maintaining their dominance among the society. Through science, human feels his weaknesses because there are so many natural secrets that have not been reached by religious thought.

Religion has been the foundation of humans in the past. It is seems disappointing because it is only a way of legitimizing power, thus religion and God have been manipulated. Science has also experienced the same thing in this century. Science has caused instability, dehumanization and even annihilation of humans, because it has become an "arrogant lighthouse". It seems that the foundation for a more prosperous human future is on the collaboration of science and religion. However, it must be noted that the greatest hope of human will be realized, not only in the fundamental changes in attitudes and thinking among scientists, but also among religious circles $^{26}$.

The conflict between religion and science will occur if each party does not protect and respect their autonomy. Scientific truth will continue to be sacrificed and humanity will be harmed when the autonomy of science is not recognized and when political and religious power dogmatically intervenes in the internal determination of scientific truth. The aspiration to

25 Johnson, "Individual Religiosity and Orientation towards Science," Sociological Science 2, no. March (2015): 108-110.

${ }_{26}$ Fatkhul Muin, "Konvergensi Islam Dan Sains Dalam Perpektif Filsafat," Miqot XXXIX, no. 2 (2015): 244-246. 
pursue rational, objective and universal truth will run aground. On the other hand, scientists have exceeded the limits of their authority if it based on their scientific authority that they reject the truth of a religious teaching.

Different starting points between science and religion which are very conflict-prone and filled with tension must be avoided, by placing oneself in parallel, by maintaining the autonomy of each party and by avoiding excessive intervention. Religion defines goals and gives meaning of life, whereas science helps provide the means to achieve these goals and obtain these meanings. Science and religion must be seen from as something complementary not confrontational. If religion can provide ethicalaxiological criticism of science, then science must be given the opportunity to criticize religion from an empirical-pragmatic point of view 27 .

When this happen in the future, religion that makes sense not only for the beleiver of a religion along with rationality of human beings will be able to co-exsist. We must find God in what we know, not in what we don't know. God is far but humans can "reach and find" Him through His creation. Humans are given the authority to manage and complete their world. By using knowledge, humans no longer need to "bribe" and "fear" God. Every trouble and suffering experienced is directly submitted to God. As a result, God is like a human support, who is "in demand" only when people are overwhelmed by suffering. Besides, how powerless is God to create creatures (humans) who are completely incapable so that humans always bound to their creator. Therefore, humans are invited and invite themselves to become co-creators of the world, prepare the world and become active agents in saving the world by optimally developing all the gifts of humanity that God has given to them.

Science and religion can exist peacefully if it reaches the level of perfection, where science and religion are at the omega level according to Teilhand de Chardin. Also, Einstein had warned that religion without science is blind and science without religion is lame. Mutual control between science and religion is very important. However, it does not mean that both of them can intervene freely with each other and can violate their respective autonomy. Therefore, it is necessary to have a consistent intersubjective dialogue between science and religion, and its existence in human life is truly useful.

27 Jonathon McPhetres, "Religiosity Predicts Negative Attitudes Towards Science and Lower Levels f Science Literacy," Plosone (2018): 1-2. 


\section{F. Religion and Science: Collaboration in Humanitarian Challenges}

The advancement of science was originally intended to facilitate human work. However, science has created new anxiety and fear for human life. The advancement of science, which was originally intended to facilitate human affairs, causes the emergence of "loneliness" and "isolation", such as the fading of the sense of solidarity, togetherness and friendship. If humans do not realize this, they will be lonely and lose something which is very important. At the end of the day, humans will be increasingly unaware of their true needs.

Humanitarian crises occur not only as a result of the advancement of science but also as a result of incomplete trends, ideologies and ideas. Recently, humans are very dependent on science. This dependency makes them becomes unaware about their free and creative existences. Human is not aware that he has been imprisoned by science and human are no longer creative and reflective. Human were used to be imprisoned and determined by nature and God, but nowadays humans are imprisoned and determined by science. Thus, it can be said that due to the advancement of science, many aspects of human life are imprisoned 28

Humans must be aware that science is a goal but it is just a tool in facilitating life. If we do not want to lose our human existence and avoid a humanitarian crisis, we must fight to free ourselves from the confines of science and return to our original existence as creative and dynamic human beings. Therefore, a religious perspective is indispensable in the heuristic context of the development of science and technology.

Religion and science are different in some ways but in others ways they are similar. Religion prioritizes morality and preserves established traditions, which tend to be exclusive and subjective. Meanwhile, science is always looking for new, progressive, inclusive and objective. Even though there are differences between religion and science, they share things in common, as in seeking truth and in providing peace and convenience to humans. Religion provides peace from the inner side; meanwhile science provides convenience for life 29

The characteristics of religion and science should not be seen as different things in affecting human life, but they must be seen as a partner or rather a collaboration that synergizes with each other in helping human

28 Eva Dewi, "Potret Pendidikan Di Era Globalisasi," Sukma: Jurnal Pendidikan 3, no. 1 (2019): 97.

29 Juhana Nasrudin, "Relasi Agama, Magi, SAINS Dengan Sistem Pengobatan Tradisional-Moderan Pada Masyarakat Pedesaan," Hanifiya: Jurnal Studi Agama-Agama 2, no. 1 (2019): 46-48. 
life and in dealing with humanitarian challenges. Science becomes negative when it is seen as something that is regressing and destroying human values. Religion is being questioned by human rationality when it changes the appearance of the physical world. The manifestation of religious wisdom is defeated by a rationality which always technically sees problems as physical realm.

As the advancement of science, it seems difficult to maintain the religiosity that has been followed from generation to generation. There must be a changing dimension because religion doesn't exsist only in the normative level. It also has historical and sociological aspects in accordance with the ages and the society. Therefore, excessive action in religion will harm and destroy the meaning of religion. Religiosity cannot be realized by force because it will only satisfy the feelings of a group of religionist and it will sacrifice the feelings of another group of religious communities. On the other hand, in order to adjust the advancement of ages and to rid heresy in religion, the application of rationality in religion carried out by those who want to modernize religion is necessary. Rationality impoverishes religion because religion is more than just human empirical data ${ }^{30}$

Religion is the main factor that shaped patterns of humans' perception. These perceptions influence the development of the world and history of human life. Religion and science are both designing the future of humanity. Religion is designing the future of humans' life that are more abstract; meanwhile science are designing the present life of humans that are more concrete

Science uses sharp intuition, while religion uses intuition (revelation) as a way to prove the truth and appreciate its essence. In order to collaborate religion and science in human life, they must be treated in a balance way. It means that religion must be used based on its portion and science must also be used based on its portion for the convenience of human life.

All differences of opinion in the terms of ideological, political, economic, social, cultural and religious should be put in a harmonious and balanced perspective. Science can be paralyzed by the effects of human life. It is similar to the religion. Science must be readjusted; it must be demonstrated. On the other hand, the believer of a religion should be trained to be more open-minded. It is important to see religion as more than just a belief; it is also a perspective and value system that is open to others who are different from the believer of that religion. Through

30 Eka Safitri, "Aplikasi Integrasi Interkonekasi Keilmuan Di Lembaga Pendidikan Tinggi," Tadrib V, no. 1 (2019): 125-126. 
collaboration between religion and science, a balance will be created in human civilization, thus, overcomes humanity's challenges.

\section{G. The Future Science and Religion}

The relationship between science and religion has colored the history of human life. Ian G. Barbour argues that there are four typologies of the relationship between science and religion in human life. They are the typology of conflict, independence, dialogue, and integration. A typology of conflict occurs when science and religion suspect each other. Science considers religion as an obstacle and religion consider science to be too progressive and it interferes with the credibility of religion. The typology of independence occurs when science and religion live separately in human life. A typology of dialogue exists when science and religion are compared to one and another. It finds out the similarity between science and religion. Finally, the typology of integration, this typology is associated with finding out the agreement and complementarily aspect between science and religion $^{31}$ see also Dian Nur Anna ${ }^{32}$, see also Mahfudz Junaedi ${ }^{33}$, see also Damanhuri, ${ }^{34}$ see also Mustofa Umar ${ }^{35}$,

According to Bertrand Russell, science and religion are two battles occurring in human life. Dogmatically, in religion, we are given an understanding of the existence of transcendental forces. However, a positive mindset makes people only believe in reality since it is experienced concretely. Gradually, the belief in the transcendental disappeared. As a result, religion, which is intended to embed the transcendence ideas in humans, fades away from the minds and hearts of its adherents. The

31 Selvia Santi, "Relasi Agama Dan Sains Menurut Seyyed Hossein Nasr Dan Ian G. Barbour," Prosediang Konferensi 1, no. September (2018): 174-175, https://movisa.org.mx/images/NoBS_Report.pdf.

32 Dian Nur Anna, "Metode Sains Menurut IAIN G. Baobour Dan Sumbangannya Terhadap Pengkajian Islam," Religi XIV, no. 1 (2017): 59-62, http:/ / www.ncbi.nlm.nih.gov/ pubmed/7556065\%0Ahttp:/ / www.pubmedcentra 1.nih.gov/articlerender.fcgi?artid=PMC394507\%0Ahttp://dx.doi.org/10.1016/j.hu mpath.2017.05.005\%0Ahttps://doi.org/10.1007/s00401-018-1825-

z\%0Ahttp://www.ncbi.nlm.nih.gov/pubmed/27157931.

33 Mahfudz Junaedi, "Mengkritisi Tipologi Hubungan Sains Dan Agama IAIN G Barbour," Jurnal Ilmiah Studi Islam 2, no. 2 (2018): 549-54, https://movisa.org.mx/images/NoBS_Report.pdf.

${ }^{34}$ Damanhuri, “Integrasi," Refleksi 151, no. 1 (2015): 40-42.

35 Mustofa Umar, "Konvergensi Agama Dan Sains Dalam Melacak Basis Ontologi Semesta: Tinjauan Hermeneutika Hadis Penciptaan," Jurnal Theologia 27, no. 1 (2016): 184. 
development of science influences human choices. Humans are always faced with two characteristics of science and religion; finite, particular, and self-centered and, infinite, universal, and impartial ${ }^{36}$, see also Luke Ferretter, ${ }^{37}$ see also sarah 38

On the contrary, Teilhard de Chardin claims that spirituality is the ultimate reality. All human aspects are covered by a spiritual perspective. Human life that interacts with science leads to a spiritual dimension. The aspect of spirituality is a dimension that claims everything in the universe, although at different levels of intensity. In the material world, the aspect of spirituality still exists. Science is related to the material world, so science still has aspects of spirituality ${ }^{39}$ see also Sara Lumbreras ${ }^{40}$

Religion is considered irrelevant to the advancement of human lives in different ages. There has been a shift from a belief in religion to believing in science. Science has become a "new religion" that is capable of answering various human needs. The sacred metaphysical aspect begins to disappear from human life and everything is seen only materially. It is what the traditional circle or religionist rejects. According to them, everything has an essence and it is reality. One fundamental characteristic of science is its expansionary nature, the desire to master all aspects of human life, the way of life, and the way of thinking.

There is an assumption that emerged in the Middle Ages that separate religion from human life or to eliminate religion from human life. This happens because of human incapability to adapt and to accommodate the development of modern society with the knowledge that they have. The advancement of society and the belief in science has finally developed out of control, especially out of control of religion. Science developed in a secular way eventually surfaced. All religious needs seem to be fulfilled

36 Michael Silberstein, "Re-Thingking The Word With Neutral Monism: Removing the Boundaries Between Mind, Matter and Spacetime," Entripy 20, no. 1 (2020): 2-4, https://doi.org/10.1016/j.tmaid.2020.101607\%0Ahttps://doi.org/10.1016/j.ijsu.20 20.02.034\%0Ahttps://onlinelibrary.wiley.com/doi/abs/10.1111/cjag.12228\%0Ahtt ps://doi.org/10.1016/j.ssci.2020.104773\%0Ahttps://doi.org/10.1016/j.jinf.2020.04 $.011 \% 0$ Ahttps://doi.org/10.1016.

${ }^{37}$ Betrand, A Prison for Te Infinite.

38 Sara Lumbreras, "Pensamiento," Pensamieto 151, no. 2013 (2015): 13841386.

39 Anto Čartolovni, “Teilhard de Chardin's Oeuvre within an Ongoing Discussion of a Gene Drive Release for Public Health Reasons," Life Sciences, Society and Policy 13, no. 1 (2017): 40504.

${ }^{40}$ Lumbreras, "Pensamiento." 
through science. However, science betrays human trust. Scientific advancement refers to disaster and destruction for humans.

In the era of globalization and information, religion has begun to attract the attention of many people. However, there is a difference between the conditions of religion when it first surfaced with the current condition of religion. A new form of religion appeared to more dogmatic, it means that religion is understood and accepted following the dogma presented. Religious dogmatism is given the nuances of the rationality of its adherents, what is understood in religion is not inaccessible or sacred; instead, it is deeply rooted in human rationality.

Moral offerings and religious information are no longer appreciated by a group of believers. Inevitably, people's thoughts and understanding of religion have always been evolving. It can be said that religion is a product of history. Human's perspective on nature, history, and religion will always evolve. In science, we have seen many old discoveries replaced by more valid discoveries. It is similar to religion; many ancient religions have disappeared because they could not withstand attacks and criticism. Some religions still survive today even though they are still being questioned by demythologization, secularization, and criticism that are related to the epistemology and rationality of religion in human life.

Since humans are creative in designing their future, they should be able to free themselves from mechanistic and manipulative diversity in modern science. Undeniably, humans often assign God to satisfy their ego; they have exploited and manipulated God's existence in their lives. This diversity creates conflict between religion and modern science.

Therefore, it is time for religionists and scientists to assign religion and science together because they cannot be separated in human life. Religious teachings strongly support the exploration of the universe in the form of science. It seems illogical if religion is considered anti-science. When science is considered to be contrary to religious teachings, it means that there is manipulation that is committed by a handful of people. The religion of the future should emphasize spiritual awareness that is supported by science. This support enables a clear cosmological map to emerge, and humans will be aware of their position in time and space.

\section{H. Conclusion}

The ebb and flow of the relationship between science and religion in affecting human life are determined by the justification of the truth of science and religion. In the middle Ages (scholasticism), the truth claiming religion was absolute; there was no opportunity in accepting scientific justification in human life. On the other hand, in the modern age, the 
justification of science exceeds the justification of religion. Religion becomes marginalized and it doesn't have a place in human life. As a result, the contemporary century emerges as a critique of modern scientific justification. Thus, in the contemporary century, there is acceptance or recognition of the justification of the truth of science and religion.

Following the philosophical concept of the contemporary century that truth is plural and partial, scientific truth is accepted and religious truth is also accepted within their circumstances. Therefore, future science and religion that rely on the power of empirical science and mystical spiritual awareness will be collaborated and synergized. Science and religion play in their portions and see other perspectives as a different perspective[.]

\section{REFERENCES}

Anggun Zuhaida, Nur Hasanah, Wulan Izzatul Himmah. "Model Madrasah Sains Integratif: Menakar Konsep Dan Strategi Pembelajaran Berbasis Relasi Sains Dan Agama." Inferensi: Jurnal Penelitian Sosial Keagamaan 12, no. 2 (2018): 439-440.

Anna, Dian Nur. "Metode Sains Menurut IAIN G. Baobour Dan Sumbangannya Terhadap Pengkajian Islam." Religi XIV, no. 1 (2017): 59-62.

http://www.ncbi.nlm.nih.gov/pubmed/7556065\%0Ahttp://www.p ubmedcentral.nih.gov/articlerender.fcgi?artid=PMC394507\%0Ahttp:

//dx.doi.org/10.1016/j.humpath.2017.05.005\%0Ahttps://doi.org/10 .1007/s00401-018-1825-

z\%0Ahttp://www.ncbi.nlm.nih.gov/pubmed/27157931.

Aprison, Wedra. "Mendamaikan Sains Dan Agama." Pendidikan Silam IV, no. 2 (2015): 2015.

Aripudin, Iis. "Integrasi Sains Dan Agama Dan Implikasinya Terhadap Pendidikan Islam." Jurnal Edukasia Islamika I, no. 1 (2016): 162-163.

Betrand, D. H. Lawrence adn. A Prison for Te Infinite, n.d.

Čartolovni, Anto. "Teilhard de Chardin's Oeuvre within an Ongoing Discussion of a Gene Drive Release for Public Health Reasons." Life Sciences, Society and Policy 13, no. 1 (2017): 40504.

Damanhuri. "Integrasi." Refleksi 151, no. 1 (2015): 40-42.

Dewi, Eva. "Potret Pendidikan Di Era Globalisasi." Sukma: Jurnal Pendidikan 3, no. 1 (2019): 97.

Fchoer, Rd. Datoek A. "Sekularitas Dan Sekularisme Agama." Religious: Jurnal Agama dan Lintas Budaya 1, no. September (2016): 99.

Harrison, Peter. The Territories Science and Religion. Laondon: The University of Chacago Press, 2015. 
Hidayat, Fahri. "Pengembangan Paradigma Integrasi Ilmu: Harmonisasi Islam Dan Sains Dalam Pendidikan." Jurnal Pendidikan ISlam IV, no. 2 (2015): 302.

Hidayatullah, Syarif. "Agama Dan Sains: Sebuah Kajian Tentang Relasi Dan Metodologi." Jurnal Filsafat 29, no. 1 (2019): 118-120.

- - - . "Konsep Ilmu Pengetahuan Syed Hussein Nashr: Suatu Telaah Relasi Sains Dan Agama." Jurnal Filsafat 28, no. 1 (2020): 116-117.

Johnson. "Individual Religiosity and Orientation towards Science." Sociological Science 2, no. March (2015): 108-110.

Juanda, Anda. "Penetrasi Agama Dan Ilmu Sains Berbasis Model Kurikurum Grass Roots Perguruan Tinggi." Educatia: Jurnal sains dan Pendidikan Sains 5, no. 1 (2016): 71-72.

Junaedi, Mahfudz. "Mengkritisi Tipologi Hubungan Sains Dan Agama IAIN G Barbour." Jurnal Ilmiah Studi Islam 2, no. 2 (2018): 549-54. https://movisa.org.mx/images/NoBS_Report.pdf.

Lumbreras, Sara. "Pensamiento." Pensamieto 151, no. 2013 (2015): 13841386.

Luthfiyah. "Mengurai Kebekuan Hubungan Agama Dan Sains Melalui Pemahaman Saintific Method Perspektif." Muaddib: Studi Kependidikan dan Keislaman 09, no. 01 (2019): 81-84.

McPhetres, Jonathon. "Religiosity Predicts Negative Attitudes Towards Science and Lower Levels f Science Literacy." Plosone (2018): 1-2.

Miftah, Muhammad. "Model Integrasi Sains Dan Agama Dalam Pendidikan Nasional." Jurnal Penelitian 14, no. 2 (2017): 235-236.

Muhammad Zaini, Mulyadi Abdul Wahid dan Abd Mujahid Hamdan. "Alquran and Modern Geoscience." Elkawnie: Journal of Islamic Science and Technology 6, no. 1 (2020): 15-16.

Muhammmad Ainul Yaqin, Evi Widia Astuti, Cindy Elsa Anggraini dan Ahmad Fauzan Hidayatullah. "Integrasi Ayat-Ayat Al-Quran Dalam Pembelajaran Sains (Biologi) Berdasarkan Pemikiran IAN G. Barbour" (n.d.): 78-79.

Muin, Fatkhul. "Konvergensi Islam Dan Sains Dalam Perpektif Filsafat." Miqot XXXIX, no. 2 (2015): 244-246.

Nasrudin, Juhana. "Relasi Agama, Magi, SAINS Dengan Sistem Pengobatan Tradisional-Moderan Pada Masyarakat Pedesaan." Hanifiya: Jurnal Studi Agama-Agama 2, no. 1 (2019): 46-48.

Nugroho, Irham. "Positivisme Auguste Comte: Analisa Epistemologis Dan Nilai Etisnya Terhadap Sains,." Cakrawala XI, no. 2 (2016): 170-171.

Priyatna, Muhammad. “Telaah Kritis Konsep Ide Besar (Fritjof Capra), Anything Goes (Paul Peyerabend) Dan Krisis Sains Modern (Richard Tarnas) Dalam Upaya Rekontruksi Pemikiran Pendidikan Islam." 
Edukasi Islami: Jurnal Pendidikan Islam 08, no. 01 (2019): 125-126.

Sacks, Kenneth S. "Auguste Comte and Consensus Formation in Religious Thought." Religions (2017): 4.

Safitri, Eka. "Aplikasi Integrasi Interkonekasi Keilmuan Di Lembaga Pendidikan Tinggi." Tadrib V, no. 1 (2019): 125-126.

Santi, Selvia. "Relasi Agama Dan Sains Menurut Seyyed Hossein Nasr Dan Ian G. Barbour." Prosediang Konferensi 1, no. September (2018): 174175. https://movisa.org.mx/images/NoBS_Report.pdf.

Sarbaini, al Barra. "Agama Dalam Perfektif Masyarakat Madani." AthThariq 02, no. 01 (2017): 4.

Silberstein, Michael. "Re-Thingking The Word With Neutral Monism: Removing the Boundaries Between Mind, Matter and Spacetime." Entripy 20, no. 1 (2020): 2-4. https://doi.org/10.1016/j.tmaid.2020.101607\%0Ahttps:// doi.org/10. 1016/j.ijsu.2020.02.034\%0Ahttps:/ / onlinelibrary.wiley.com/doi/abs /10.1111/cjag.12228\%0Ahttps://doi.org/10.1016/j.ssci.2020.104773\% 0Ahttps://doi.org/10.1016/j.jinf.2020.04.011\%0Ahttps://doi.org/10. 1016.

Syarif, Edwin. “Pergulatan Sains Dan Agama.” 201313 (2013): 648-652.

Umar, Mustofa. "Konvergensi Agama Dan Sains Dalam Melacak Basis Ontologi Semesta: Tinjauan Hermeneutika Hadis Penciptaan." Jurnal Theologia 27, no. 1 (2016): 184.

Wahyudi, Chafid. "Etika Publik Sebagai Ruang Dialog Agama." Hikmatuna 1, no. 1 (2015): 36-37.

Walt, Izak J. Van Der. "Reformed Theology and Natural Science: Conflict or Concurrence" (2020).

Zaprulkhan. "Membangun Relasi Agama Dan Ilmu Pengetahuan." kalam: Jurnal Studi Agama dan Pemikiran Islam 4, no. 1 (2019): 261-264. 